\title{
Geochemical characteristics of sandstones from Cretaceous Garudamangalam area of Ariyalur, Tamilnadu, India: Implications of provenance and tectonic setting
}

\author{
BABU K \\ Department of Civil Engineering, Bannari Amman Institute of Technology, \\ Sathyamangalam, Erode 638 401, India. \\ e-mail:geokbabu@gmail.com
}

The Trichinopoly Group (later redesignated as Garudamangalam) has unconformable relationship with underlying Uttatur Group and is divided into lower Kulakanattam Formation and upper Anaipadi Formation. These calcareous sandstones are analysed major, trace and rare earth elements (REEs) to find out CIA, CIW, provenance and tectonic setting. The silica content of fossiliferous calcareous sandstone show wide variation ranging from 12.93 to $42.56 \%$. Alumina content ranged from 3.49 to $8.47 \%$. Higher values of $\mathrm{Fe}_{2} \mathrm{O}_{3}(2.29-22.02 \%)$ and low $\mathrm{MgO}$ content (0.75-2.44\%) are observed in the Garudamangalam Formation. $\mathrm{CaO}(23.53-45.90)$ is high in these sandstones due to the presence of calcite as cementing material. Major element geochemistry of clastic rocks $\left(\mathrm{Al}_{2} \mathrm{O}_{3}\right.$ vs. $\left.\mathrm{Na}_{2} \mathrm{O}\right)$ plot and trace elemental ratio $(\mathrm{Th} / \mathrm{U})$ reveal the moderate to intense weathering of the source rocks. The $\mathrm{Cr} / \mathrm{Zr}$ ratio of clastic rocks reveal with an average of 1.74 suggesting of felsic provenance. In clastic rocks, high ratios of

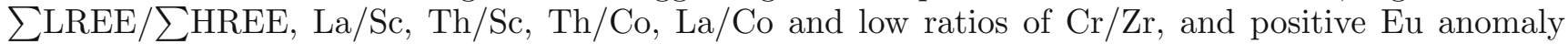
ranges from $\left(\mathrm{Eu} / \mathrm{Eu}^{*}=1.87-5.30\right)$ reveal felsic nature of the source rocks.

\section{Introduction}

The Cretaceous period was one of the most eventful time spans in the Indian geological history. The study area occupies one of the important palaeogeographical locations in Indo-Pacific region during the Cretaceous period. The Cretaceous successions of Tiruchirapalli district, Tamilnadu, are the best developed and Blanford (1862) was the first to work out the stratigraphy and he named three groups: the Uttatur, the Trichinopoly and the Ariyalur (figure 1). The geology and stratigraphy of this area are accounted by Ramarao (1956); Ramanathan (1968); Banerji (1972); Sastry et al. (1972); ONGC (1977); Sundaram and Rao (1979, 1986); Ramasamy and Banerji (1991); Banerji et al.
(1996) and many others. The geochemistry of clastic sediments has been effectively used for the evaluation of tectonic setting and provenance determination (Bhatia 1983; McLennan et al. 1983; Taylor and McLennan 1985; Roser and Korsch 1986, 1988; Condie et al. 1992; Condie 1993). Though, the chemical record of clastic sedimentary rocks is affected by many other factors, such as chemical weathering, transport distance, sorting processes during transport, sedimentation and post-depositional diagentic reactions (McLennan 1989; Nesbitt and Young 1996; Nesbitt et al. 1996), still if the influence of these processes is minor (e.g., the first cycle sandstones), the composition of siliclastic rocks predominantly reflect the nature and proportion of their detrital

Keywords. Sandstone; geochemistry; provenance; Garudamangalam Formation; Ariyalur; India. 


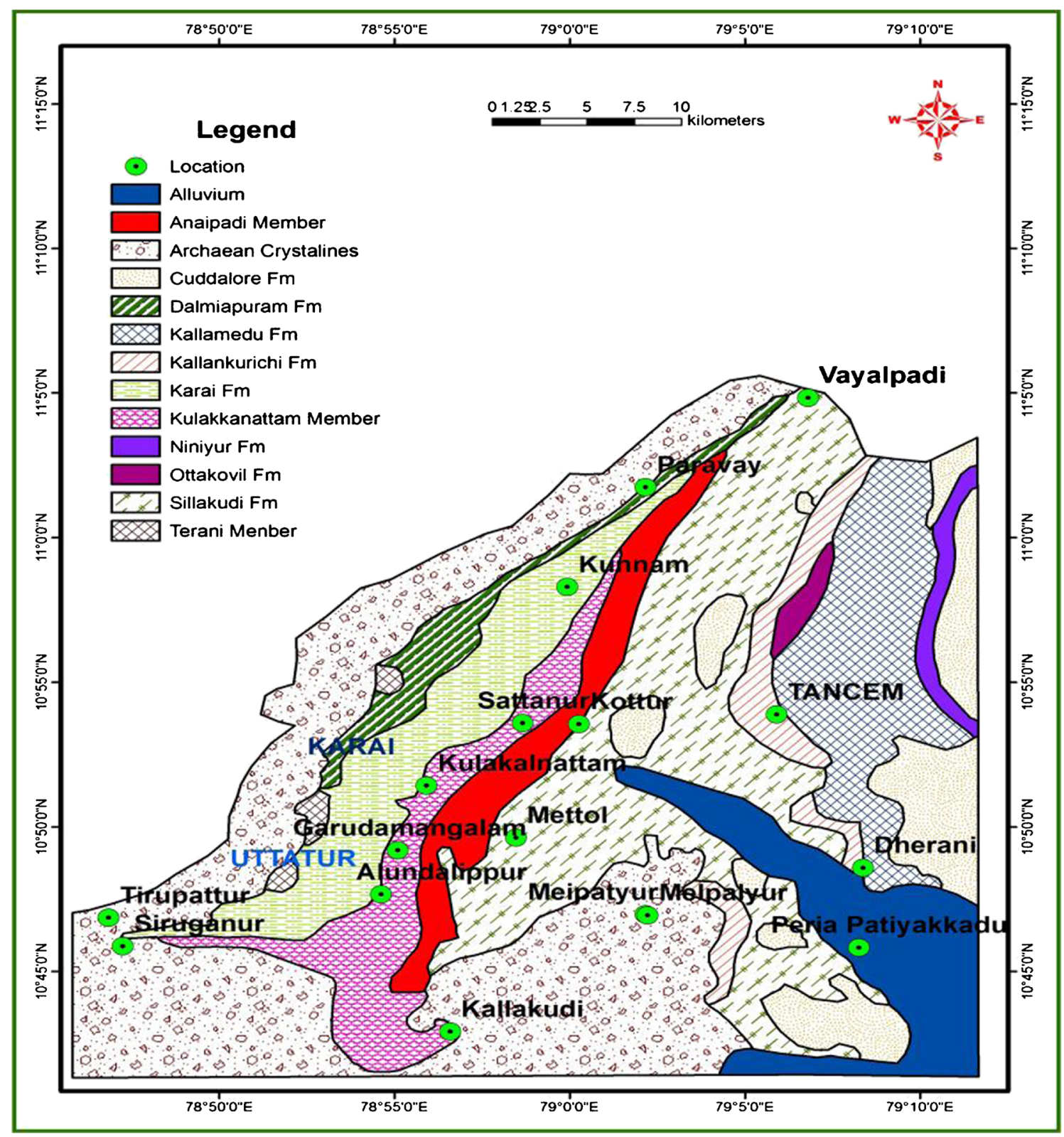

Figure 1. Location map of the study area.

components and hence their provenance (Bhatia and Crook 1986; Roser and Korsch 1986). Bhatia (1983) classified the tectonic settings of sedimentary basins, containing significant wackes, into four main types: Oceanic Island Arc (OIA), Continental Island Arc (mainly sourced from felsic volcanic rocks), Active Continental margin (ACM) and Passive margin (PM) on the basis of relative enrichment and depletion of the mobile and immobile elements. Other authors (Bhatia and Crook 1986; Roser and Korsch, op.cit.) have also presented different discrimination diagrams by which one can infer the provenance and tectonic settings of sandstone. The classification proposed by Sundaram et al. (2001) has been followed in this study. Many have worked in this formation in palaeontological and lithostratigraphic aspects only. No existing data for this formation is found in geochemical study. This paper reveals Garudamangalam Formation in geochemical characterization of sandstones.

\section{Geological setting}

The Trichinopoly Group (later redesignated as Garudamangalam) has unconformable relationship with underlying Uttatur Group and it is separated into lower Kulakanattam Formation and upper Anaipadi Formation (Sundaram and Rao 1986). The Kulakanattam Formation comprises of conglomerate bands, hard calcareous sandstone, 
fossilliferous limestone, pebbly and cobbly sandstone, soft sandstone, clays, shales and silt. The lower portion is mainly composed of hard calcareous sandstone bands which are conglomeratic in nature. The middle portion is predominantly clays, while the upper one is made up of sequences of shell limestone, soft sandstone, calcareous shales and clays. The maximum width of $5.5 \mathrm{~km}$ is noticed in the southern portion of the basin, which gradually narrows down towards the north-east (50$100 \mathrm{~m}$ ). A conglomerate band with $700 \mathrm{~m}$ width is noticed near Kottarai, which is formed due to intense drag folding (Sundaram et al. 2001).

Anaipadi Formation is further divided into two members, the lower member comprises of shale, silt, sandy clays, limestone bands and calcareous sandstone. It is well developed near Anaipadi village and the total thickness is about $164 \mathrm{~m}$. The upper member is mainly composed of yellowish or reddish sands/sandstone with minor bands of fossiliferous grit. The total thickness is around $75 \mathrm{~m}$ and these two members merge towards the northern end. As a result, yellowish sandy clay and lenses of highly fossiliferous calcareous sandstone occur alternatively. These two members merge into a sequence of alternating shale, clay and soft argillaceous sandstone beds towards its southern extremity.

\section{Methodology}

Field/outcrops features, such as bed geometry, texture, sedimentary structure, erosional surfaces, etc., serve as evidence for depositional environments. Such features are carefully observed in the field. Field techniques also included documentation of the geometry of features (description, photos, and measurements). Field descriptions were aided with the use of a $10 \times$ hand lens, dilute $\mathrm{HCl}$ (to test for carbonate cement) and grain size chart (to standardize grain size descriptions). Samples were collected for geochemical analysis from beds of representative and variable lithologies. Extensive field work was carried out by using 1:50000 scale maps for the period of 6 months in the Perambalur and Ariyalur area. The traverse-wise collection of these samples in general dip direction has helped to study their variation in stratigraphic order. In addition, samples were also collected from isolated patches, stream sections, well cuttings, quarry sections and shallow boreholes. Totally 200 samples were collected from 10 traverses. The following are 10 traverses selected for the present study:

1. Kulakanattam-Gudalur,

2. Anaipadi-Kulattur,

3. Nallur-Garudamangalam-Saradamangalam,
4. Sirukalpur-Alundalaipur-MelArasur,

5. Peruvalapur-Varakuppai-Kallakudi,

6. Siruvayalur-Tappy-Kallakudi,

7. Nattakadu-Sattanur-Pilimisai,

8. Kottarai-Adanur,

9. Odiyam-Moongilpadi-Periyammapalayam, and 10. Kunnam (figure 2).

Samples were analysed for major oxides using XRF by R\&D Centre, India Cements Ltd, Dalavoi. Rare earth element (REE) was determined for representative samples using ICP-MS at Shiva Analyticals Pvt Ltd, Bangalore. The ICP-Mass Spectrometer used for this work is the Plasma Quad PQl (Fisons Instruments, UK) controlled by an IBM PC-XT micro computer and necessary software.

\section{Results}

\subsection{Major elements}

Ten samples of fossiliferous calcareous gritty sandstones were analyzed and the results are given in table 1 . Five samples were analyzed trace and REE concentrations are listed in tables 2 and 3 . The elemental variations of major and trace elements shown in tables 4 and 5 . The silica content of fossiliferous calcareous sandstone show wide variation ranging from 12.93 to $42.56 \%$. Alumina content ranging from 3.49 to $8.47 \%$. Higher values of $\mathrm{Fe}_{2} \mathrm{O}_{3}$ $(2.29-22.02 \%)$ and low $\mathrm{MgO}$ content $(0.75-2.44 \%)$ are observed in the Garudamangalam Formation. $\mathrm{CaO}(23.53-45.90)$ is high in these sandstones due to the presence of calcite as cementing material. $\mathrm{K}_{2} \mathrm{O}$ content is ranging from 0.44 to $1.62 \% . \mathrm{Na}_{2} \mathrm{O}$ $(0.25-2.01 \%)$ is depleted. $\mathrm{TiO}_{2}(0.20-0.60 \%)$ due to their high quartz contents and lesser mafic components (Shilin Liu et al. 2007) and $\mathrm{MnO}$ (0.05-0.40\%) are consistently low.

Chemical classification of samples from the Garudamangalam Formation sandstones based on well-classified scattergrams $\log \left(\mathrm{SiO}_{2} / \mathrm{Al}_{2} \mathrm{O}_{3}\right)$ vs. $\log \left(\mathrm{Na}_{2} \mathrm{O} / \mathrm{K}_{2} \mathrm{O}\right)$ and $\log \left(\mathrm{SiO}_{2} / \mathrm{Al}_{2} \mathrm{O}_{3}\right)$ vs. $\log \left(\mathrm{Fe}_{2} \mathrm{O}_{3} / \mathrm{K}_{2} \mathrm{O}\right)$ (figure 3). The $\log \left(\mathrm{SiO}_{2} / \mathrm{Al}_{2} \mathrm{O}_{3}\right)$ vs. $\log \left(\mathrm{Na}_{2} \mathrm{O} / \mathrm{K}_{2} \mathrm{O}\right)$ scattergram shows that sandstones of the studied samples predominantly fall in the litharenite. The $\log \left(\mathrm{SiO}_{2} / \mathrm{Al}_{2} \mathrm{O}_{3}\right)$ vs. $\log \left(\mathrm{Fe}_{2} \mathrm{O}_{3} /\right.$ $\mathrm{K}_{2} \mathrm{O}$ ) scattergram shows that the same sandstone samples dominantly fall in the Fe-sand field (figure 4), through a few samples mark an Feshale field, and a couple of samples of the Garudamangalam Formation shift to the shale field of the diagram. The shift of sandstone to various fields is due to a wide range in the variation of relative proportion of matrix, feldspar and lithic components (Lindsey et al. 2003). Variation in $\mathrm{Na}_{2} \mathrm{O} / \mathrm{K}_{2} \mathrm{O}$ on $\log \left(\mathrm{SiO}_{2} / \mathrm{Al}_{2} \mathrm{O}_{3}\right)$ scattergrams may 


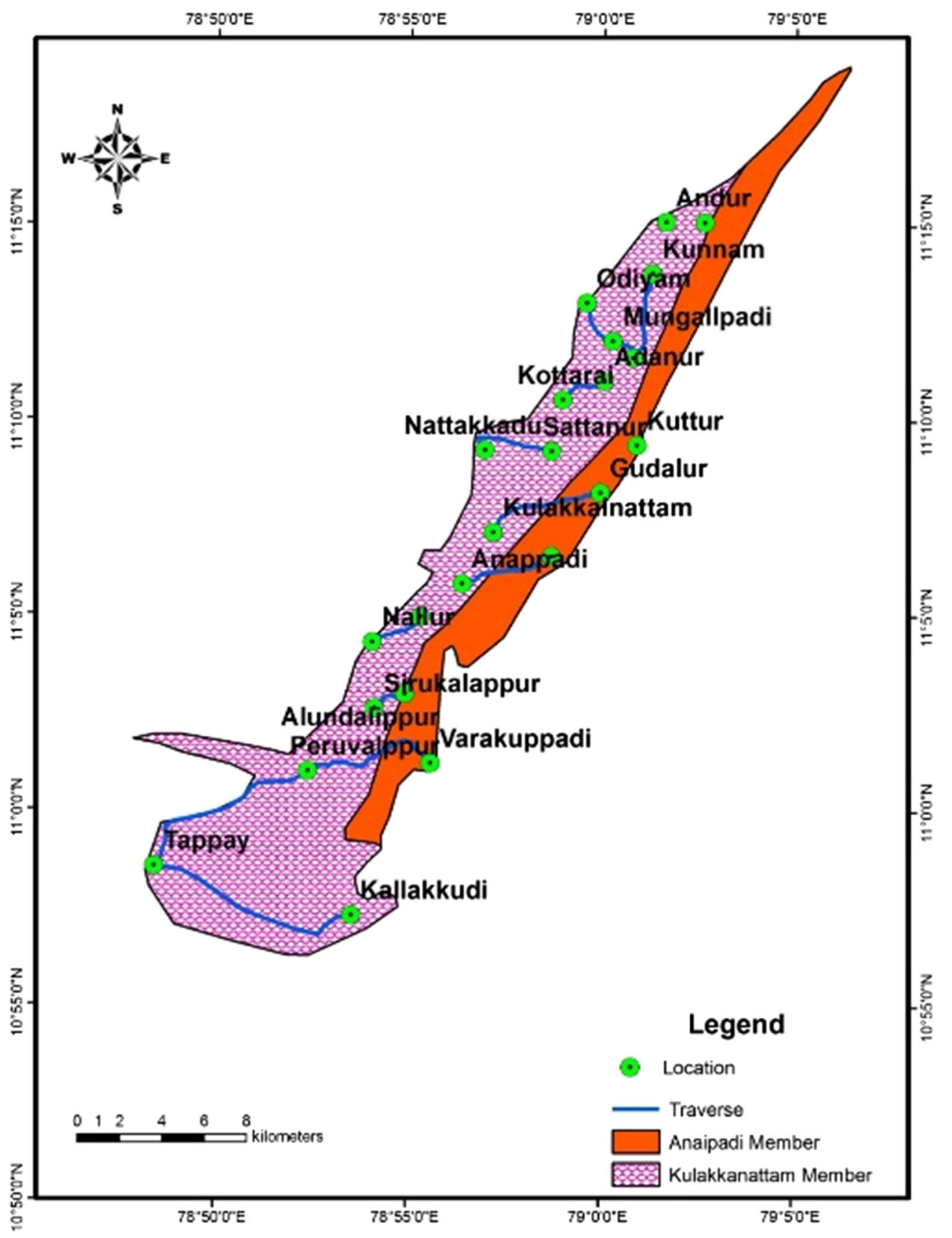

Figure 2. Map showing sample locations and traverses of Garudamangalam Formation.

Table 1. Major element concentration of sandstone in Garudamangalam Formation.

\begin{tabular}{|c|c|c|c|c|c|c|c|c|c|c|c|c|c|}
\hline Sample & $\mathrm{SiO}_{2}$ & $\mathrm{Al}_{2} \mathrm{O}_{3}$ & $\mathrm{Fe}_{2} \mathrm{O}_{3}$ & $\mathrm{CaO}$ & $\mathrm{MgO}$ & $\mathrm{S}$ & $\mathrm{Na}_{2} \mathrm{O}$ & $\mathrm{K}_{2} \mathrm{O}$ & $\mathrm{MnO}$ & $\mathrm{TiO}_{2}$ & $\mathrm{P}_{2} \mathrm{O}_{5}$ & LOI & Total \\
\hline SKR-53 & 12.93 & 3.49 & 4.20 & 45.90 & 0.86 & 0.05 & 0.60 & 0.44 & 0.40 & 0.20 & 0.05 & 30.67 & 99.79 \\
\hline TAY-60 & 24.82 & 8.4 & 5.83 & 33.16 & 1.52 & 0.06 & 1.37 & 1.24 & 0.24 & 0.49 & 0.04 & 22.5 & 99.66 \\
\hline PL-27 & 42.1 & 5.63 & 5.78 & 27.45 & 0.75 & 0.09 & 1.21 & 0.58 & 0.16 & 0.32 & 0.05 & 15.6 & 99.70 \\
\hline PL-25 & 42.56 & 5.09 & 2.29 & 27.61 & 2.44 & 0.03 & 0.95 & 0.51 & 0.08 & 0.29 & 0.04 & 17.89 & 99.78 \\
\hline PAM-13 & 18.84 & 5.41 & 22.02 & 23.53 & 1.81 & 0.05 & 0.25 & 1.62 & 0.30 & 0.55 & 0.21 & 25.19 & 99.77 \\
\hline $\mathrm{KT}-7$ & 32.91 & 6.42 & 3.31 & 33.26 & 1.06 & 0.06 & 1.29 & 0.49 & 0.18 & 0.53 & 0.04 & 20.09 & 99.62 \\
\hline PVR-57 & 39.92 & 8.2 & 3.48 & 27.69 & 0.99 & 0.03 & 1.82 & 1.33 & 0.21 & 0.34 & 0.05 & 15.62 & 99.69 \\
\hline ANP-40 & 39.55 & 6.21 & 3.69 & 29.48 & 1.20 & 0.06 & 1.39 & 0.55 & 0.30 & 0.60 & 0.03 & 16.58 & 99.65 \\
\hline MAR'62 & 25.75 & 6.46 & 3.09 & 36.26 & 1.36 & 0.05 & 1.01 & 1.41 & 0.05 & 0.45 & 0.075 & 23.48 & 99.45 \\
\hline APM-35 & 28.15 & 8.47 & 3.53 & 34.16 & 1.44 & 0.04 & 2.01 & 0.64 & 0.30 & 0.41 & 0.02 & 20.31 & 99.48 \\
\hline
\end{tabular}


Table 2. Trace element concentration of Garudamangalam sandstone.

\begin{tabular}{|c|c|c|c|c|c|}
\hline Sample & PL-25 & KT-7 & ANP-40 & PVR-57 & TAY-60 \\
\hline $\mathrm{Li}$ & 1.4 & 3.0 & 2.6 & 2.5 & 9.8 \\
\hline $\mathrm{Be}$ & 0.5 & 0.5 & 0.5 & 1.1 & 0.8 \\
\hline $\mathrm{Sc}$ & 2.8 & 4.6 & 5.6 & 5.2 & 6.0 \\
\hline Co & 5.5 & 16.9 & 7.8 & 7.2 & 11.9 \\
\hline $\mathrm{Ga}$ & 8.4 & 6.3 & 10.2 & 15.2 & 4.2 \\
\hline $\mathrm{Ge}$ & 0.5 & 0.5 & 0.5 & 0.5 & 0.5 \\
\hline $\mathrm{Rb}$ & 6.6 & 6.9 & 7.4 & 18.0 & 28.3 \\
\hline $\mathrm{Y}$ & 3.5 & 6.8 & 7.6 & 8.0 & 7.9 \\
\hline $\mathrm{Zr}$ & 12.3 & 16.1 & 20.9 & 19.9 & 21.8 \\
\hline $\mathrm{Nb}$ & 2.6 & 0.5 & 0.5 & 0.5 & 5.8 \\
\hline Mo & 2.0 & 2.1 & 1.8 & 1.6 & 2.4 \\
\hline $\mathrm{Ag}$ & 0.5 & 0.5 & 0.5 & 0.5 & 0.5 \\
\hline $\mathrm{Cd}$ & 0.5 & 0.5 & 0.5 & 0.5 & 0.5 \\
\hline In & 0.5 & 0.5 & 0.5 & 0.5 & 0.5 \\
\hline Sn & 0.5 & 0.5 & 0.5 & 0.5 & 0.5 \\
\hline $\mathrm{Sb}$ & 0.7 & 0.7 & 0.7 & 0.8 & 0.7 \\
\hline $\mathrm{Te}$ & 0.5 & 0.5 & 0.5 & 0.5 & 0.5 \\
\hline Cs & 0.5 & 0.5 & 0.5 & 0.5 & 0.6 \\
\hline Hf & 0.5 & 0.6 & 0.9 & 0.8 & 0.9 \\
\hline Ta & 0.5 & 0.5 & 0.5 & 0.5 & 0.5 \\
\hline W & 0.5 & 0.5 & 0.5 & 0.5 & 1.2 \\
\hline $\mathrm{Pb}$ & 8.6 & 12.7 & 0.5 & 30.4 & 27.1 \\
\hline $\mathrm{Bi}$ & 0.5 & 0.5 & 0.5 & 0.5 & 0.5 \\
\hline $\mathrm{Th}$ & 1.0 & 1.2 & 2.3 & 1.2 & 3.1 \\
\hline $\mathrm{U}$ & 0.5 & 0.5 & 0.5 & 0.5 & 0.5 \\
\hline $\mathrm{Ba}$ & 387 & 817 & 1246 & 720 & 778 \\
\hline $\mathrm{Sr}$ & 309 & 358 & 383 & 399 & 434 \\
\hline $\mathrm{Ti}$ & 1492 & 3249 & 3518 & 2020 & 2882 \\
\hline $\mathrm{Cu}$ & 40.1 & 19.2 & 15.2 & 15.0 & 16.8 \\
\hline $\mathrm{Pb}$ & 6.5 & 9.6 & 5.0 & 22.8 & 20.3 \\
\hline $\mathrm{Zn}$ & 51.8 & 51.9 & 50.4 & 51.9 & 66.0 \\
\hline $\mathrm{Ni}$ & 10.8 & 17.2 & 15.3 & 20.1 & 35.6 \\
\hline $\mathrm{Cr}$ & 11.7 & 41.9 & 27.0 & 35.3 & 42.5 \\
\hline V & 29.7 & 42.8 & 49.7 & 45.0 & 61.8 \\
\hline
\end{tabular}

have been resulted from (a) mixing of two source rocks, one $\mathrm{K}_{2} \mathrm{O}$-rich (i.e., potassium feldspar) and one $\mathrm{Na}_{2} \mathrm{O}$-rich (plagioclase), or (b) varying degrees of weathering of initially $\mathrm{Na}_{2} \mathrm{O}$-rich (plagioclase) rock either in the source area or during transit to the depositional basin, or both.

If $\log \left(\mathrm{Na}_{2} \mathrm{O} / \mathrm{K}_{2} \mathrm{O}\right)$ values represent mixing of two rock types, then the ratios at the ends of the line should approximate those of the source rocks. If $\log \left(\mathrm{Na}_{2} \mathrm{O} / \mathrm{K}_{2} \mathrm{O}\right)$ represents weathering of an originally $\mathrm{Na}_{2} \mathrm{O}$ (plagioclase)-rich rock, then the ratio at the $\mathrm{Na}_{2} \mathrm{O}$-rich end of the trend should approximate the value of the source (Kafayatullah 2009). Commonly, in unmetamorphosed arkosic rocks, weathering of the source area and sediment during transit is the probable cause of variation in $\log \left(\mathrm{Na}_{2} \mathrm{O} / \mathrm{K}_{2} \mathrm{O}\right)$. Furthermore, all the sandstone
Table 3. REE composition and ratios of Garudamangalam sandstone.

\begin{tabular}{|c|c|c|c|c|c|}
\hline Sample & PL-25 & $\mathrm{KT}-7$ & ANP-40 & PVR-57 & TAY-60 \\
\hline La & 7.7 & 13.5 & 11.2 & 10.2 & 23.3 \\
\hline $\mathrm{Ce}$ & 12.7 & 26.0 & 25.4 & 29.3 & 36.4 \\
\hline $\operatorname{Pr}$ & 0.5 & 1.0 & 1.1 & 0.8 & 1.6 \\
\hline $\mathrm{Nd}$ & 4.4 & 8.8 & 8.7 & 7.0 & 13.9 \\
\hline $\mathrm{Sm}$ & 1.1 & 2.1 & 2.1 & 2.0 & 3.4 \\
\hline $\mathrm{Eu}$ & 0.5 & 0.9 & 1.1 & 1.1 & 1.2 \\
\hline $\mathrm{Gd}$ & 0.9 & 1.7 & 2.0 & 1.7 & 2.5 \\
\hline $\mathrm{Tb}$ & 0.5 & 0.5 & 0.5 & 0.5 & 0.5 \\
\hline Dy & 0.9 & 1.7 & 1.9 & 2.0 & 2.2 \\
\hline Но & 0.5 & 0.5 & 0.5 & 0.5 & 0.5 \\
\hline Er & 0.6 & 1.0 & 1.1 & 1.3 & 1.3 \\
\hline $\mathrm{Tm}$ & 0.5 & 0.5 & 0.5 & 0.5 & 0.5 \\
\hline $\mathrm{Yb}$ & 1.2 & 1.5 & 1.4 & 1.5 & 1.5 \\
\hline $\mathrm{Lu}$ & 0.5 & 0.5 & 0.5 & 0.5 & 0.5 \\
\hline $\mathrm{La}_{\mathrm{N}} / \mathrm{Yb}_{\mathrm{N}}$ & 0.46 & 0.68 & 0.59 & 0.51 & 1.18 \\
\hline $\mathrm{La}_{\mathrm{N}} / \mathrm{Sm}_{\mathrm{N}}$ & 0.98 & 0.94 & 0.78 & 0.75 & 0.99 \\
\hline $\mathrm{Sm} / \mathrm{Nd}$ & 0.26 & 0.24 & 0.24 & 0.28 & 0.25 \\
\hline $\mathrm{Gd}_{\mathrm{N}} / \mathrm{Yb}_{\mathrm{N}}$ & 0.46 & 0.73 & 0.85 & 0.70 & 1.05 \\
\hline$\sum \mathrm{REE}$ & 32.78 & 60.05 & 57.93 & 58.97 & 89.31 \\
\hline LREE & 26.56 & 51.29 & 48.43 & 49.35 & 78.62 \\
\hline HREE & 5.71 & 7.89 & 8.42 & 8.54 & 9.50 \\
\hline LREE/HREE & 4.65 & 6.50 & 5.75 & 5.78 & 8.28 \\
\hline $\mathrm{Ce} / \mathrm{Ce}^{*}$ & 0.43 & 0.61 & 0.67 & 0.73 & 0.61 \\
\hline $\mathrm{Eu} / \mathrm{Eu}^{*}$ & 5.30 & 2.89 & 2.71 & 3.00 & 1.87 \\
\hline
\end{tabular}

samples contain varying proportions of ore minerals (Van de kamp and Leake 1994; Lindsey et al. 2003).

\subsection{Harkar variation diagrams}

Harkar variation of major elements with respect to $\mathrm{SiO}_{2}$ content is shown in figure 5. All sandstones of this formation have moderate $\mathrm{SiO}_{2}$ content. In Harkar diagrams, $\mathrm{SiO}_{2}$ vs. other oxides plots $\mathrm{Al}_{2} \mathrm{O}_{3}, \mathrm{Na}_{2} \mathrm{O}$ and $\mathrm{TiO}_{2}$ show a positive correlation with a rough linear trend. Negative correlation observed for $\mathrm{Fe}_{2} \mathrm{O}_{3}, \mathrm{~K}_{2} \mathrm{O}, \mathrm{CaO}, \mathrm{MnO}, \mathrm{P}_{2} \mathrm{O}_{5}$ and LOI against $\mathrm{SiO}_{2}$. The negative correlation of $\mathrm{SiO}_{2}$ with most major elements is due to most of the silica being sequestered in quartz, as indicated by Osman (1996). A gradual decrease in $\mathrm{CaO}$, $\mathrm{MnO}$ and LOI content is observed with increase in $\mathrm{SiO}_{2}$ content. $\mathrm{Al}_{2} \mathrm{O}_{3}$ vs. $\mathrm{Fe}_{2} \mathrm{O}_{3}, \mathrm{~K}_{2} \mathrm{O}$ and $\mathrm{TiO}_{2}$ plots (figure 6) are constructed in order to obtain the distribution patterns of $\mathrm{Al}_{2} \mathrm{O}_{3}$ with other oxides. $\mathrm{Al}_{2} \mathrm{O}_{3}$ vs. $\mathrm{Fe}_{2} \mathrm{O}_{3}$ shows a negative correlation. The positive correlation observed for $\mathrm{K}_{2} \mathrm{O}$ and $\mathrm{TiO}_{2}$ against $\mathrm{Al}_{2} \mathrm{O}_{3}$, good positive correlation indicates that, the clastic sediments have moderate content of clay minerals and ferromagnesian minerals. The high $\mathrm{K}_{2} \mathrm{O}$ and $\mathrm{Al}_{2} \mathrm{O}_{3}$ content are due to 
Table 4. Major element ratios of Garudamangalam sandstone.

\begin{tabular}{lcccccccccc}
\hline Sample & SKR-53 & TAY-60 & PL-27 & PL-25 & PAM-13 & KT-7 & PVR-57 & ANP-40 & MAR'62 & APM-35 \\
\hline $\mathrm{CIA}$ & 7 & 19 & 16 & 15 & 18 & 15 & 21 & 17 & 14 & 19 \\
$\mathrm{CIW}$ & 7 & 20 & 16 & 15 & 19 & 16 & 22 & 17 & 15 & 19 \\
$\mathrm{Na}_{2} \mathrm{O} / \mathrm{K}_{2} \mathrm{O}$ & 1.38 & 1.10 & 2.10 & 1.88 & 0.15 & 2.63 & 1.37 & 2.52 & 0.72 & 3.14 \\
$\mathrm{~K}_{2} \mathrm{O} / \mathrm{Na}_{2} \mathrm{O}$ & 0.73 & 0.91 & 0.48 & 0.53 & 6.59 & 0.38 & 0.73 & 0.40 & 1.40 & 0.32 \\
$\mathrm{Fe}_{2} \mathrm{O}_{3}+\mathrm{MgO}$ & 5.06 & 7.35 & 6.53 & 4.73 & 23.83 & 4.37 & 4.47 & 4.89 & 4.45 & 4.97 \\
$\mathrm{Al}_{2} \mathrm{O}_{3} / \mathrm{SiO}_{2}$ & 0.27 & 0.34 & 0.13 & 0.12 & 0.29 & 0.20 & 0.21 & 0.16 & 0.25 & 0.30 \\
$\mathrm{SiO}_{2} / \mathrm{Al}_{2} \mathrm{O}_{3}$ & 3.70 & 2.95 & 7.48 & 8.36 & 3.48 & 5.13 & 4.87 & 6.37 & 3.99 & 3.29 \\
\hline
\end{tabular}

Table 5. Elemental ratios of Garudamangalam sandstone.

\begin{tabular}{|c|c|c|c|c|c|}
\hline Sample & PL-25 & KT-7 & ANP-40 & PVR-57 & TAY-60 \\
\hline $\mathrm{Ba} / \mathrm{Sc}$ & 140.29 & 178.06 & 221.42 & 138.16 & 129.64 \\
\hline $\mathrm{Ba} / \mathrm{Co}$ & 70.49 & 48.27 & 159.80 & 100.45 & 65.29 \\
\hline $\mathrm{Rb} / \mathrm{Cs}$ & 13.29 & 13.81 & 14.81 & 35.90 & 50.01 \\
\hline $\mathrm{Cr} / \mathrm{Th}$ & 12.03 & 34.98 & 11.88 & 28.72 & 13.82 \\
\hline $\mathrm{Rb} / \mathrm{Sr}$ & 0.02 & 0.02 & 0.02 & 0.05 & 0.07 \\
\hline $\mathrm{Cr} / \mathrm{Zr}$ & 0.95 & 2.60 & 1.29 & 1.77 & 1.94 \\
\hline $\mathrm{Cr} / \mathrm{Ni}$ & 1.08 & 2.44 & 1.77 & 1.75 & 1.19 \\
\hline $\mathrm{Zr} / \mathrm{Hf}$ & 24.57 & 26.48 & 24.28 & 25.20 & 24.14 \\
\hline $\mathrm{Zr} / \mathrm{Nb}$ & 4.75 & 32.20 & 41.82 & 39.88 & 3.74 \\
\hline $\mathrm{Th} / \mathrm{Sc}$ & 0.35 & 0.26 & 0.40 & 0.24 & 0.51 \\
\hline $\mathrm{Th} / \mathrm{U}$ & 1.94 & 2.39 & 4.54 & 2.45 & 6.15 \\
\hline $\mathrm{Th} / \mathrm{Co}$ & 0.18 & 0.07 & 0.29 & 0.17 & 0.26 \\
\hline $\mathrm{La} / \mathrm{Th}$ & 7.98 & 11.24 & 4.94 & 8.31 & 7.58 \\
\hline $\mathrm{La} / \mathrm{Sc}$ & 2.80 & 2.93 & 1.99 & 1.96 & 3.88 \\
\hline $\mathrm{La} / \mathrm{Co}$ & 1.41 & 0.80 & 1.44 & 1.42 & 1.96 \\
\hline $\mathrm{Nb} / \mathrm{Ta}$ & 5.18 & 1.00 & 1.00 & 1.00 & 11.67 \\
\hline $\mathrm{La} / \mathrm{Y}$ & 2.22 & 1.97 & 1.48 & 1.28 & 2.95 \\
\hline $\mathrm{Y} / \mathrm{Ni}$ & 0.32 & 0.40 & 0.50 & 0.40 & 0.22 \\
\hline $\mathrm{Ti} / \mathrm{Zr}$ & 121.48 & 201.76 & 168.26 & 101.30 & 131.94 \\
\hline $\mathrm{Cr} / \mathrm{Ti}$ & 0.01 & 0.01 & 0.01 & 0.02 & 0.01 \\
\hline $\mathrm{Cr} / \mathrm{V}$ & 0.39 & 0.98 & 0.54 & 0.78 & 0.69 \\
\hline $\mathrm{V} / \mathrm{Cr}$ & 2.54 & 1.02 & 1.84 & 1.28 & 1.45 \\
\hline $\mathrm{Zr} / \mathrm{Th}$ & 12.67 & 13.45 & 9.21 & 16.25 & 7.11 \\
\hline $\mathrm{Zr} / \mathrm{Sc}$ & 4.46 & 3.51 & 3.72 & 3.83 & 3.64 \\
\hline $\mathrm{Cu} / \mathrm{Zn}$ & 0.77 & 0.37 & 0.30 & 0.29 & 0.25 \\
\hline $\mathrm{Cr} / \mathrm{Sc}$ & 4.23 & 9.13 & 4.79 & 6.77 & 7.07 \\
\hline $\mathrm{La}_{\mathrm{N}} / \mathrm{Yb}_{\mathrm{N}}$ & 0.46 & 0.68 & 0.59 & 0.51 & 1.18 \\
\hline $\mathrm{LaN}_{\mathrm{N}} / \mathrm{Sm}_{\mathrm{N}}$ & 0.98 & 0.94 & 0.78 & 0.75 & 0.99 \\
\hline $\mathrm{Sm} / \mathrm{Nd}$ & 0.26 & 0.24 & 0.24 & 0.28 & 0.25 \\
\hline $\mathrm{Gd}_{\mathrm{N}} / \mathrm{Yb}_{\mathrm{N}}$ & 0.46 & 0.73 & 0.85 & 0.70 & 1.05 \\
\hline $\mathrm{Ce} / \mathrm{Ce}^{*}$ & 0.43 & 0.61 & 0.67 & 0.73 & 0.61 \\
\hline $\mathrm{Eu} / \mathrm{Eu}^{*}$ & 5.30 & 2.89 & 2.71 & 3.00 & 1.87 \\
\hline$\sum \mathrm{REE}$ & 32.78 & 60.05 & 57.93 & 58.97 & 89.31 \\
\hline 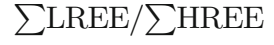 & 4.65 & 6.50 & 5.75 & 5.78 & 8.28 \\
\hline
\end{tabular}

the enrichment of clay minerals. The correlation coefficients of the major elements in studied sandstones are shown in table $6 . \mathrm{TiO}_{2}$ which is relatively immobile during weathering (Nesbitt 1979), is characteristic of ferromagnesian minerals such as biotite, amphibole, pyroxene and olivine (Sawyer 1986). The $\mathrm{K}_{2} \mathrm{O} / \mathrm{Na}_{2} \mathrm{O}$ ratio has also been used as an indicator of sandstone-type and tectonic setting (Crook 1974; Roser and Korsch 1986). This ratio is inferred to increase with sedimentary maturation as feldspars and other labile during diagenesis. Similarly, the $\mathrm{SiO}_{2} / \mathrm{Al}_{2} \mathrm{O}_{3}$ ratio has been used as an indicator of maturity in sandstones, because it increases as quartz is progressively concentrated at the expense of less resistant minerals during weathering, transport and recycling (Maynard et al. 1982; Roser and Korsch 1986). The $\mathrm{K}_{2} \mathrm{O} / \mathrm{Al}_{2} \mathrm{O}_{3}$, $\mathrm{K}_{2} \mathrm{O} / \mathrm{Na}_{2} \mathrm{O}$ plots show diffused patterns (figure 7 ).

\subsection{Trace elements}

The contents of $\mathrm{Rb}, \mathrm{Ba}, \mathrm{Cs}$ and $\mathrm{Sr}$ in the sandstones from studied formation vary to a great degree from 6.6 to $28.3,387$ to $1246,0.5$ to 0.6 , and 309 to $434 \mathrm{ppm}$, respectively. Compared with UCC (Taylor and McLennan 1985), Rb and Cs are distinctly depleted whereas $\mathrm{Ba}$ and $\mathrm{Sr}$ are strongly enriched (figure 8). The contents of $\mathrm{Cr}, \mathrm{Co}, \mathrm{Ni}$ and $\mathrm{Sc}$ show a wide range from 11.7 to $42.5,5.5$ to $16.9,10.8$ to 35.6 and 2.8 to $6 \mathrm{ppm}$, respectively. High field strength elements Th, Y and Ta show ranges from 1 to $3.1,3.5$ to 8 and 0.5 to $5.8 \mathrm{ppm}$, respectively. Compared to UCC, the concentrations of most high field strength elements are generally low (figure 8).

\subsection{Rare earth elements}

Distribution of rare earth elements in sandstone of Garudamangalam Formation and then elemental ratios are presented in table 5 . The REE concentration in the sandstone varies from 32.78 to $59.81 \mathrm{ppm}$ and $\sum L \mathrm{LEE} / \sum \mathrm{HREE}$ range from 4.65 to 8.28 . In chondrite normalized pattern of all these samples show steep depletion of LREE and more or less flattened HREE pattern with positive $\mathrm{Eu}$ anomaly $\left(\mathrm{Eu} / \mathrm{Eu}^{*}=0.87-5.30\right)$. All samples exhibit negative Ce anomaly (0.43-073). LREE ( $\mathrm{La}-\mathrm{Eu}$ ) enrichment $\mathrm{La}_{\mathrm{N}} / \mathrm{Yb}_{\mathrm{N}}=0.46-1.18$ and flat HREE $\mathrm{Gd}_{\mathrm{N}} / \mathrm{Yb}_{\mathrm{N}}=0.46-1.05$ (figure 9). 


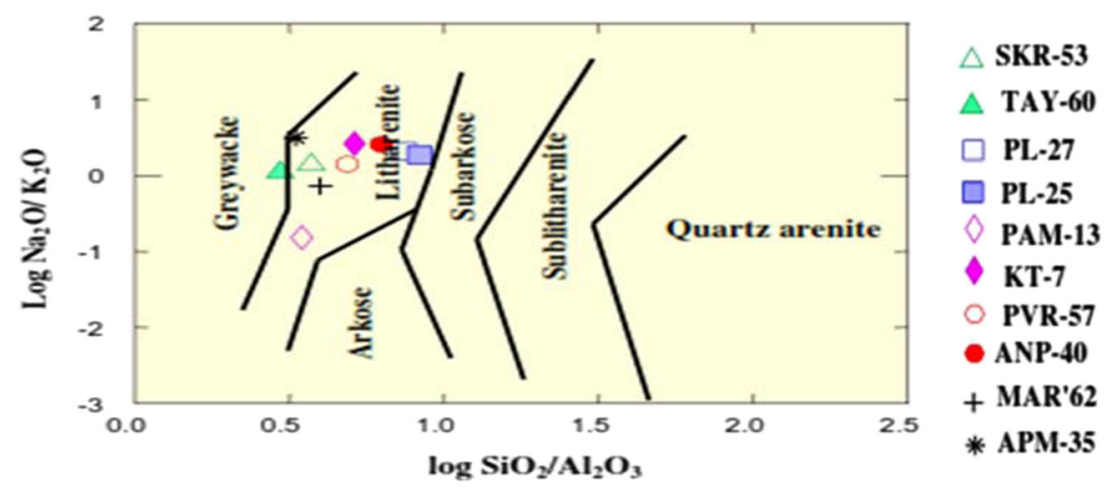

Figure 3. $\mathrm{Log}\left(\mathrm{SiO}_{2} / \mathrm{Al}_{2} \mathrm{O}_{3}\right)$ vs. $\log \left(\mathrm{Na}_{2} \mathrm{O} / \mathrm{K}_{2} \mathrm{O}\right)$ plot of the Garudamangalam Formation sandstone on a geochemical classification diagram after Herron (1988).

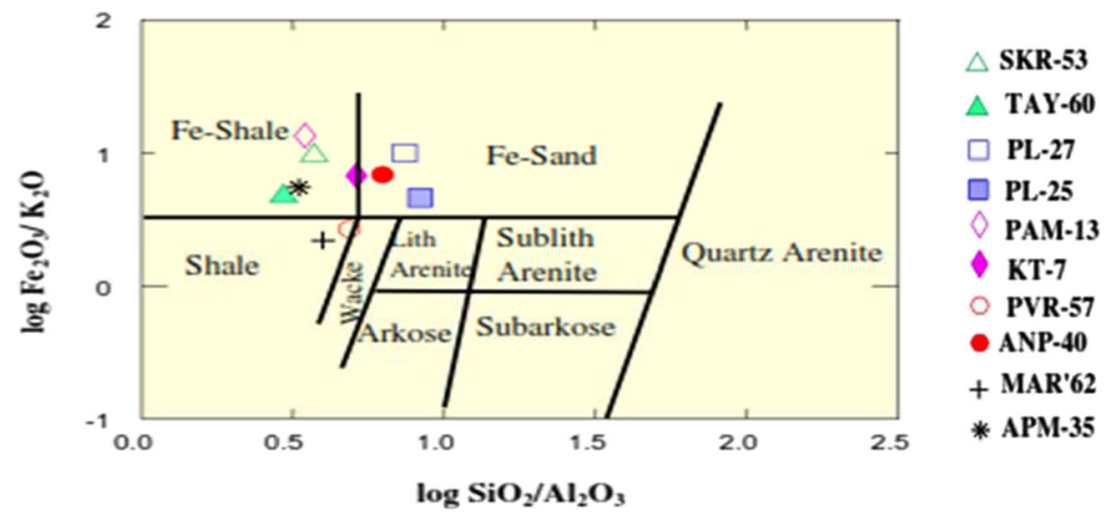

Figure 4. $\mathrm{Log}\left(\mathrm{SiO}_{2} / \mathrm{Al}_{2} \mathrm{O}_{3}\right)$ vs. $\log \left(\mathrm{Fe}_{2} \mathrm{O}_{3} / \mathrm{K}_{2} \mathrm{O}\right)$ plot of the Garudamangalam Formation sandstone on a geochemical classification diagram after Pettijohn et al. (1987).

\section{Discussion}

\subsection{Provenance and tectonic setting}

The geochemical characters of clastic rocks have been used to decipher the provenance of the source region (Taylor and McLennan 1985; Condie et al. 1992). Particularly, $\mathrm{SiO}_{2} / \mathrm{Al}_{2} \mathrm{O}_{3}$ and $\mathrm{K}_{2} \mathrm{O} / \mathrm{Na}_{2} \mathrm{O}$ ratios have been estimated to infer evolutionary changes in the composition of continental crust (Veizer 1973; Schwab 1978) and the provenance (Condie and Wronkiewicz 1990). In general, clastics of Garudamangalam Formation are enriched in quartz and have considerable amount of $\mathrm{K}$ feldapar. Plagioclase is present in small amount. Petrographically, these sandstones can be classified into arenite, wacke, subarkosic and arkosic types. The studied sandstones show large variations in $\mathrm{SiO}_{2} / \mathrm{Al}_{2} \mathrm{O}_{3}$ ratios ranging from 2.95 to 8.36 and an average of 4.97 . This is higher than some typical post-Archaean shales (2.49-4.41) from Australia (Nance and Taylor 1976; Taylor and McLennan 1985). Though the source for the quartz rich sandstones is less than for the sandstones of arenite and litharenite variety, but in all probability, they were also derived mostly from felsic nature.
The immobile nature of $\mathrm{Zr}, \mathrm{Nb}$ and $\mathrm{Y}$, and their preferentially enrichment in felsic phases during crystallization and anatexis make them a good provenance indicator (Taylor and McLennan 1985; Feng and Kerrich 1990). The studied sandstone has $\mathrm{Zr}$ ranging from 12.28 to 21.84 , averaging $18.22 \mathrm{ppm}(\mathrm{UCC}=190 \mathrm{ppm}, \mathrm{PAAS}=210 \mathrm{ppm})$, $\mathrm{Nb}$ ranging from 1 to 6 , averaging $2 \mathrm{ppm}(\mathrm{UCC}=$ $13.7 \mathrm{ppm}, \mathrm{PAAS}=19 \mathrm{ppm}$ ) and $\mathrm{Y}$ ranging from 3.48 to 7.98 , averaging $6.75 \mathrm{ppm}(\mathrm{UCC}=22$ $\mathrm{ppm}, \mathrm{PAAS}=27 \mathrm{ppm}$ ). The lower values of $\mathrm{Zr}$, $\mathrm{Nb}$, and $\mathrm{Y}$ of the studied samples thus indicate the presence of mafic phases in the source areas for these sediments. Cullers et al. (1988), Cullers (1994) and Mongelli et al. (1996) have used trace element geochemistry for provenance studies of various sediments. In this regard, Co and Sc can be used to distinguish between sediments derived from amphibolites, tonalities and other acidic rocks. Similarly, Ba was used for distinguishing silicic and basic sources of sands. But the best provenance discrimination was obtained by plotting $\mathrm{Ba} / \mathrm{Sc}$ and $\mathrm{Ba} / \mathrm{Co}$ ratios (Cullers et al. 1988). In the present study, the low average $\mathrm{Ba} / \mathrm{Co}$ and $\mathrm{Ba} / \mathrm{Sc}$ ratios of calcareous sandstone $(\mathrm{Ba} / \mathrm{Sc}=161.51$ and $\mathrm{Ba} / \mathrm{Co}=88.86)$ are significantly higher than the 

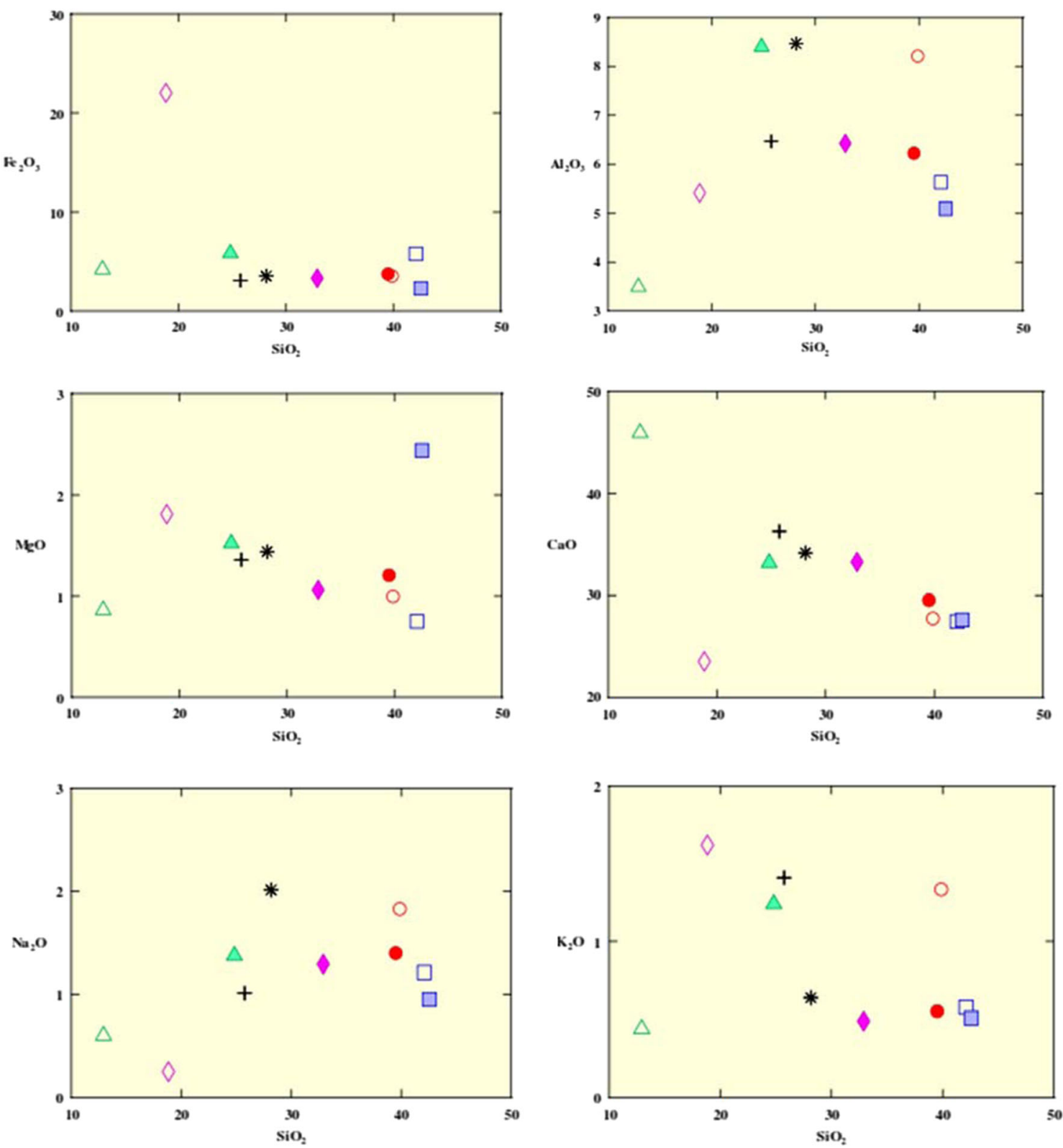

Figure 5. Harkar variation diagram of Garudamangalam sandstone.
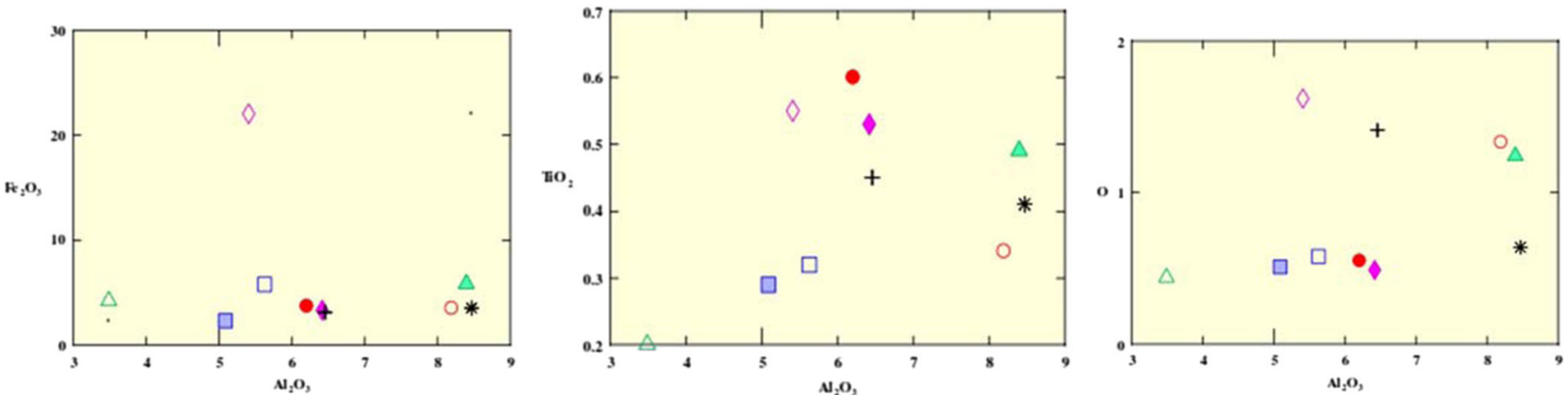

Figure 6. $\mathrm{Al}_{2} \mathrm{O}_{3}$ vs. other major oxides of Garudamangalam sandstone.

$\mathrm{UCC}(\mathrm{Ba} / \mathrm{Sc}=50$ and $\mathrm{Ba} / \mathrm{Co}=55)$ and PAAS $(\mathrm{Ba} / \mathrm{Sc}=40.62$ and $\mathrm{Ba} / \mathrm{Co}=28.26)$ and thus point to silicic as possible source for these formations.
Since elements like $\mathrm{Cr}$ and $\mathrm{Zr}$ are controlled by the chromite and zircon contents, respectively, their ratio may be good indicator of relative 
Table 6. Correlation coefficients of major oxides in Garudamangalam sandstone.

\begin{tabular}{|c|c|c|c|c|c|c|c|c|c|c|c|c|}
\hline & $\mathrm{SiO}_{2}$ & $\mathrm{Al}_{2} \mathrm{O}_{3}$ & $\mathrm{Fe}_{2} \mathrm{O}_{3}$ & $\mathrm{CaO}$ & $\mathrm{MgO}$ & $\mathrm{S}$ & $\mathrm{Na}_{2} \mathrm{O}$ & $\mathrm{K}_{2} \mathrm{O}$ & $\mathrm{MnO}$ & $\mathrm{TiO}_{2}$ & $\mathrm{P}_{2} \mathrm{O}_{5}$ & LOI \\
\hline $\mathrm{SiO}_{2}$ & 1 & & & & & & & & & & & \\
\hline $\mathrm{Al}_{2} \mathrm{O}_{3}$ & 0.25 & 1 & & & & & & & & & & \\
\hline $\mathrm{Fe}_{2} \mathrm{O}_{3}$ & -0.43 & -0.18 & 1 & & & & & & & & & \\
\hline $\mathrm{CaO}$ & -0.59 & -0.25 & -0.45 & 1 & & & & & & & & \\
\hline $\mathrm{MgO}$ & 0.06 & -0.01 & 0.23 & -0.38 & 1 & & & & & & & \\
\hline S & 0.13 & -0.18 & 0.10 & -0.08 & -0.51 & 1 & & & & & & \\
\hline $\mathrm{Na}_{2} \mathrm{O}$ & 0.50 & 0.80 & -0.62 & -0.04 & -0.25 & -0.12 & 1 & & & & & \\
\hline $\mathrm{K}_{2} \mathrm{O}$ & -0.29 & 0.36 & 0.57 & -0.34 & 0.18 & -0.20 & -0.19 & 1 & & & & \\
\hline $\mathrm{MnO}$ & -0.55 & -0.14 & 0.31 & 0.32 & -0.30 & -0.04 & -0.09 & -0.14 & 1 & & & \\
\hline $\mathrm{TiO}_{2}$ & 0.03 & 0.38 & 0.35 & -0.40 & 0.11 & 0.13 & 0.06 & 0.33 & 0.00 & 1 & & \\
\hline $\mathrm{P}_{2} \mathrm{O}_{5}$ & -0.43 & -0.29 & 0.94 & -0.40 & 0.28 & -0.03 & -0.72 & 0.66 & 0.12 & 0.27 & 1 & \\
\hline LOI & -0.96 & -0.45 & 0.33 & 0.67 & 0.01 & -0.15 & -0.62 & 0.15 & 0.46 & -0.17 & 0.38 & 1 \\
\hline
\end{tabular}
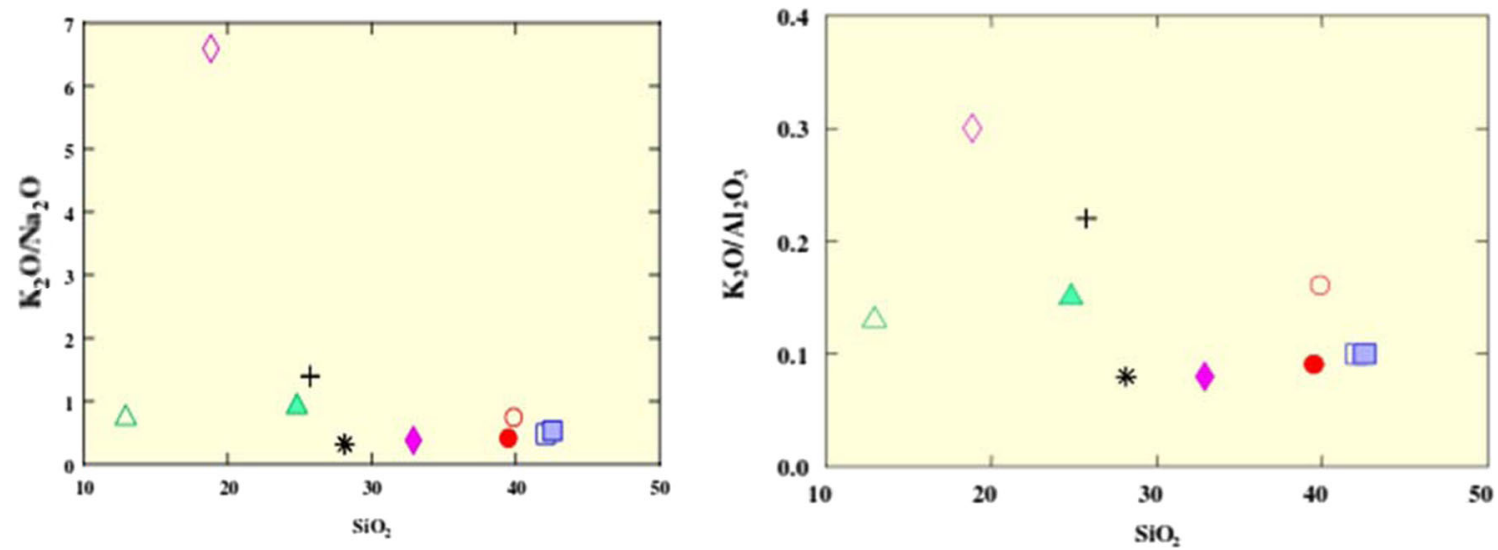

Figure 7. Plots of $\mathrm{SiO}_{2}$ vs. $\mathrm{K}_{2} \mathrm{O} / \mathrm{Na}_{2} \mathrm{O}$ and $\mathrm{K}_{2} \mathrm{O} / \mathrm{Al}_{2} \mathrm{O}_{3}$.

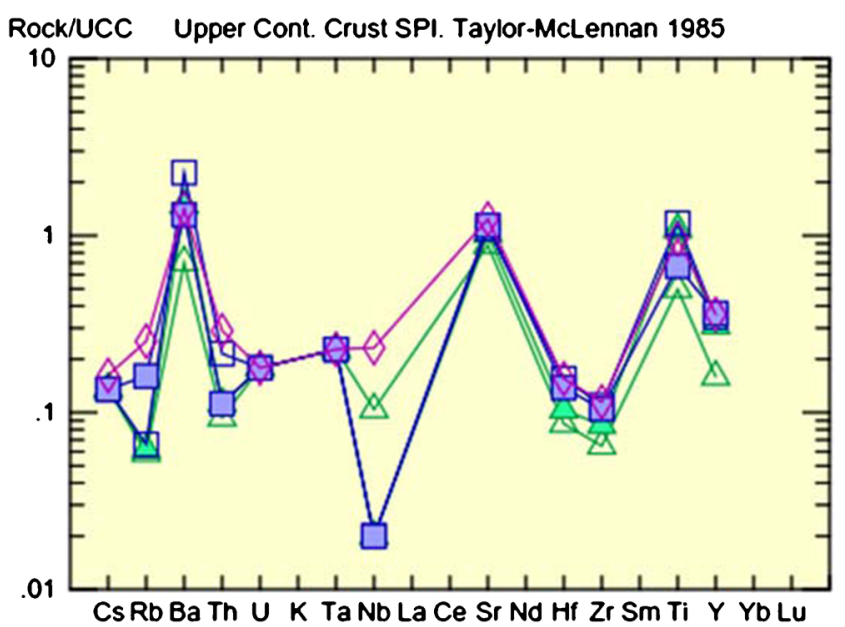

Figure 8. Comparison UCC in Garudamangalam sandstone.

influx of komatiite(mafic)/granite(felsic) sources (Wronkiewicz and Condie 1989). The Garudamangalam calcareous sandstone have $\mathrm{Cr} / \mathrm{Zr}$ ratios ranging from 0.95 to 2.60, averaging 1.71 . The high $\mathrm{Cr} / \mathrm{Zr}$ ratio in sandstone is the result of selective sorting of heavy minerals. These ratios are greater

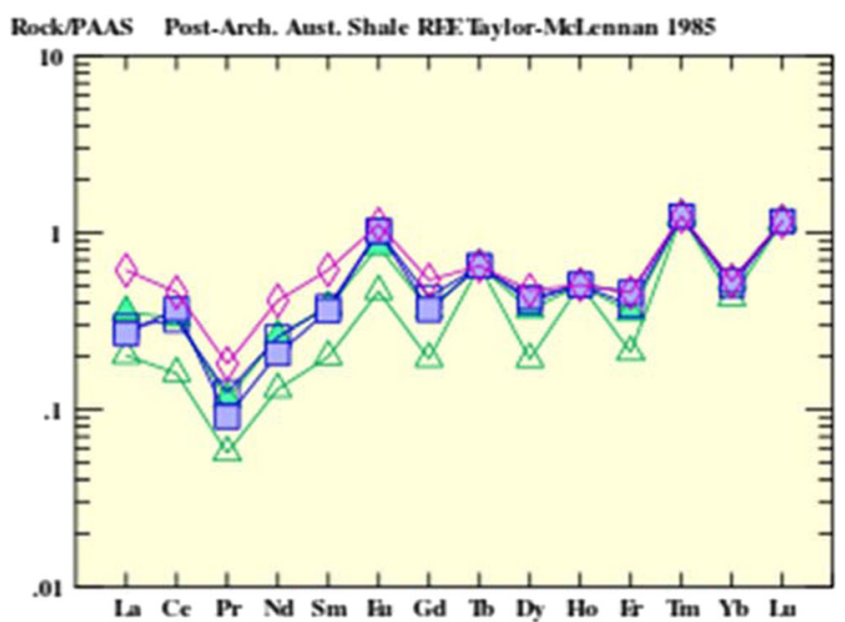

Figure 9. PAAS normalized REE diagram sandstone of Garudamangalam Formation.

than the UCC and PAAS. The Sc/Th ratio of the studied sandstone reflects the relative contributions of (basalt+komatiite)/granite. Felsic source rocks usually contain lower concentrations of $\mathrm{Cr}$, $\mathrm{Co}, \mathrm{Ni}$ and $\mathrm{V}$ and high concentrations of $\mathrm{Ba}, \mathrm{Sr}, \mathrm{Y}$ and $\mathrm{Zr}$ than mafic and intermediate source rocks 


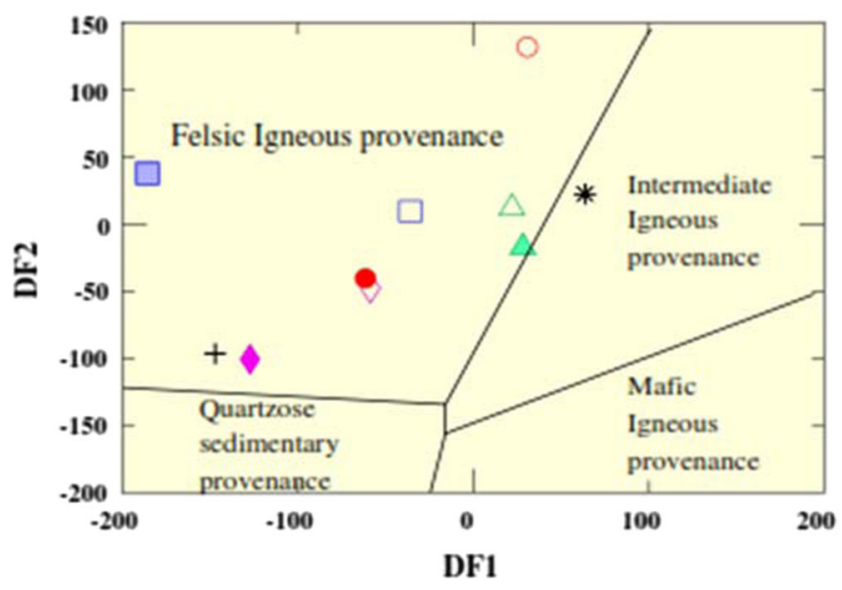

Figure 10. Discrimination diagram of Garudamangalam sandstone (after Roser and Korsch 1986).

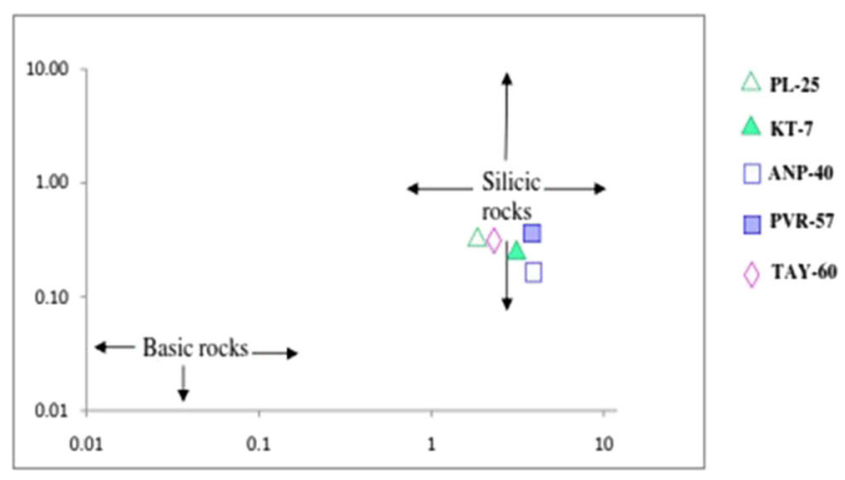

Figure 11. Th/Co vs. La/Sc plot showing source rock composition for the Garudamangalam sandstone (fields after Cullers 2002).

(Taylor and McLennan 1985; Wronkiewicz and Condie 1989; Spalletti et al. 2008). The respective average values of the studied clac.sandstone samples $(\mathrm{Cr}=31.64, \mathrm{Ni}=19.79, \mathrm{Co}=9.86$, and $\mathrm{V}=45.79)$. The discrimination diagrams for sedimentary provenance after Roser and Korsch (1986), all samples of the studied sandstone plot in the felsic igneous provenance field (figure 10). Variations in $\mathrm{Th}$ and $\mathrm{La}$ (indicative of felsic) and Sc and Co (indicative of mafic) contents have been used to differentiate between felsic and mafic provenance by various authors (McLennan et al. 1980; Cullers 2002; Nagarajan et al. 2007a, b; Kasanzu et al. 2008). Th/Co vs. La/Sc bivariate plot and $\mathrm{La}-\mathrm{Th}-\mathrm{Sc}$ triangular diagrams can provide information regarding the source rock characteristics (McLennan and Taylor 1991; Cullers 2002). The Th/Co vs. La/Sc plot (figure 11) suggests a felsic nature of the source rocks (Cullers 2002). Similarly, La-Th-Sc triangular diagram (figure 12) is also used to understand the provenance characteristics. The average compositions of granite, andesite and basalt (Condie 1993), and

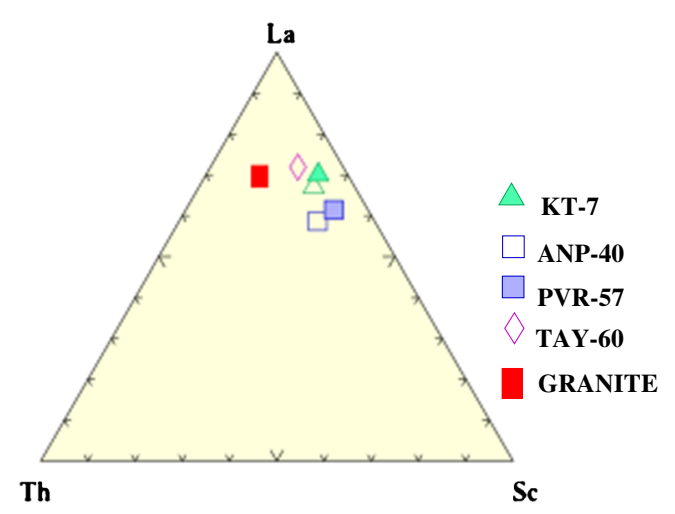

Figure 12. La-Th-Sc ternary diagram for Garudamangalam sandstone (Condie 1993).

UCC are used in this diagram for comparsion. In this triangular diagram calcareous sandstone plots near to granite composition, suggests that the Garudamangalam calcareous sandstone were derived probably by the influence of felsic source rocks. The elemental ratios of studied sandstone compared to ratios of similar fractions derived from felsic rocks, mafic rocks and upper continental crust (UCC) are shown in table 7 .

The $\mathrm{Fe}_{2} \mathrm{O}_{3}+\mathrm{MgO}$ vs. $\mathrm{TiO}_{2}, \mathrm{Fe}_{2} \mathrm{O}_{3}+\mathrm{MgO}$ vs. $\mathrm{K} 2 \mathrm{O} / \mathrm{Na}_{2} \mathrm{O}$ and $\mathrm{Fe}_{2} \mathrm{O}_{3}+\mathrm{MgO}$ vs. $\mathrm{Al}_{2} \mathrm{O}_{3} / \mathrm{SiO}_{2}$ diagrams of Bhatia (1983) produce clear picture of the provenance for the Garudamangalam Formation (figure 13). The study area sandstone samples are dominantly fall in the Continental Island Arc field. The $\mathrm{K}_{2} \mathrm{O} / \mathrm{Na}_{2} \mathrm{O}$ range from 0.32 to 6.54 with an average of 1.24 indicates the destruction of plagioclase is higher than the K-feldspar. Th/U ratio is also useful to study the source characteristics of clastic sedimentary rocks (Rodazz et al. 2006; Bakkiaraj et al. 2010). The higher $\mathrm{Th} / \mathrm{U}$ ratios in the sediments are due to oxidative weathering, and removal of $U$ and $\mathrm{Th} / \mathrm{U}$ increases with kaolinite content in highly weathered rocks (McLennan et al. 1980). Clastic sedimentary rocks derived from the upper crust are characterized by $\mathrm{Th} / \mathrm{U}$ ratios equal to or $>4$, whereas $\mathrm{Th} / \mathrm{U}$ ratios $<4$ have been related to mantle contribution (Roddaz et al. 2006). Clastic rocks of Garudamangalam Formation show much variation in $\mathrm{Zr} / \mathrm{Nb}$ ratios across different formations. The average value of $\mathrm{Zr} / \mathrm{Nb}$ ratio is 24.48 which is higher than that of present day continental crust $(\mathrm{Zr} / \mathrm{Nb}=12.7)$. The $\sum$ LREE/ $\sum$ HREE ratios show restricted variation on study area formation and it ranges from 4.65 to 8.28 with an average of 6.19 . The observed higher values of $\sum$ LREE/ $\sum$ HREE show that the clastic sediments of Garudamangalam Formation was derived from felsic source. In studied sandstone, samples exhibit positive $\mathrm{Eu}$ anomaly $\left(\mathrm{Eu} / \mathrm{Eu}^{*}\right)$ ranging from 1.87 to 5.30 with enriched LREE and depleted HREE patterns. 
Table 7. Range of elemental ratios of Garudamangalam calcareous sandstone in this study compared to the ratios in similar fractions derived from felsic rocks, mafic rocks and upper continental crust (UCC).

\begin{tabular}{lcccc}
\hline $\begin{array}{l}\text { Elemental } \\
\text { ratio }\end{array}$ & $\begin{array}{c}\text { Range of sandstone } \\
\text { from Garudamangalam } \\
\text { Formation }\end{array}$ & $\begin{array}{c}\text { Range of sediment } \\
\text { from felsic sources }\end{array}$ & $\begin{array}{c}\text { Range of sediment } \\
\text { from mafic sources }\end{array}$ & UCC $^{3}$ \\
\hline $\mathrm{Eu} / \mathrm{Eu}^{*}$ & $1.87-5.30$ & $0.40-0.94$ & $0.71-0.95$ & 0.63 \\
$(\mathrm{La} / \mathrm{Lu})_{\mathrm{cn}}$ & $0.18-0.53$ & $3.00-27.00$ & $1.10-7.00$ & 9.73 \\
$\mathrm{La} / \mathrm{Sc}$ & $1.96-3.88$ & $2.5-16.3$ & $0.43-0.86$ & 2.21 \\
$\mathrm{Th} / \mathrm{Sc}$ & $0.24-0.51$ & $0.84-20.5$ & $0.05-0.22$ & 0.79 \\
$\mathrm{Th} / \mathrm{Co}$ & $0.07-0.29$ & $0.67-19.4$ & $0.04-1.4$ & 0.63 \\
$\mathrm{Th} / \mathrm{Cr}$ & $0.03-0.08$ & $0.13-2.7$ & $0.018-0.046$ & 0.13 \\
$\mathrm{Cr} / \mathrm{Th}$ & $11.18-34.98$ & $4.00-15.0$ & $25-500$ & 7.76 \\
$\mathrm{La} / \mathrm{Co}$ & $0.80-1.96$ & $1.80-13.8$ & $0.14-0.38$ & 1.76 \\
\hline
\end{tabular}
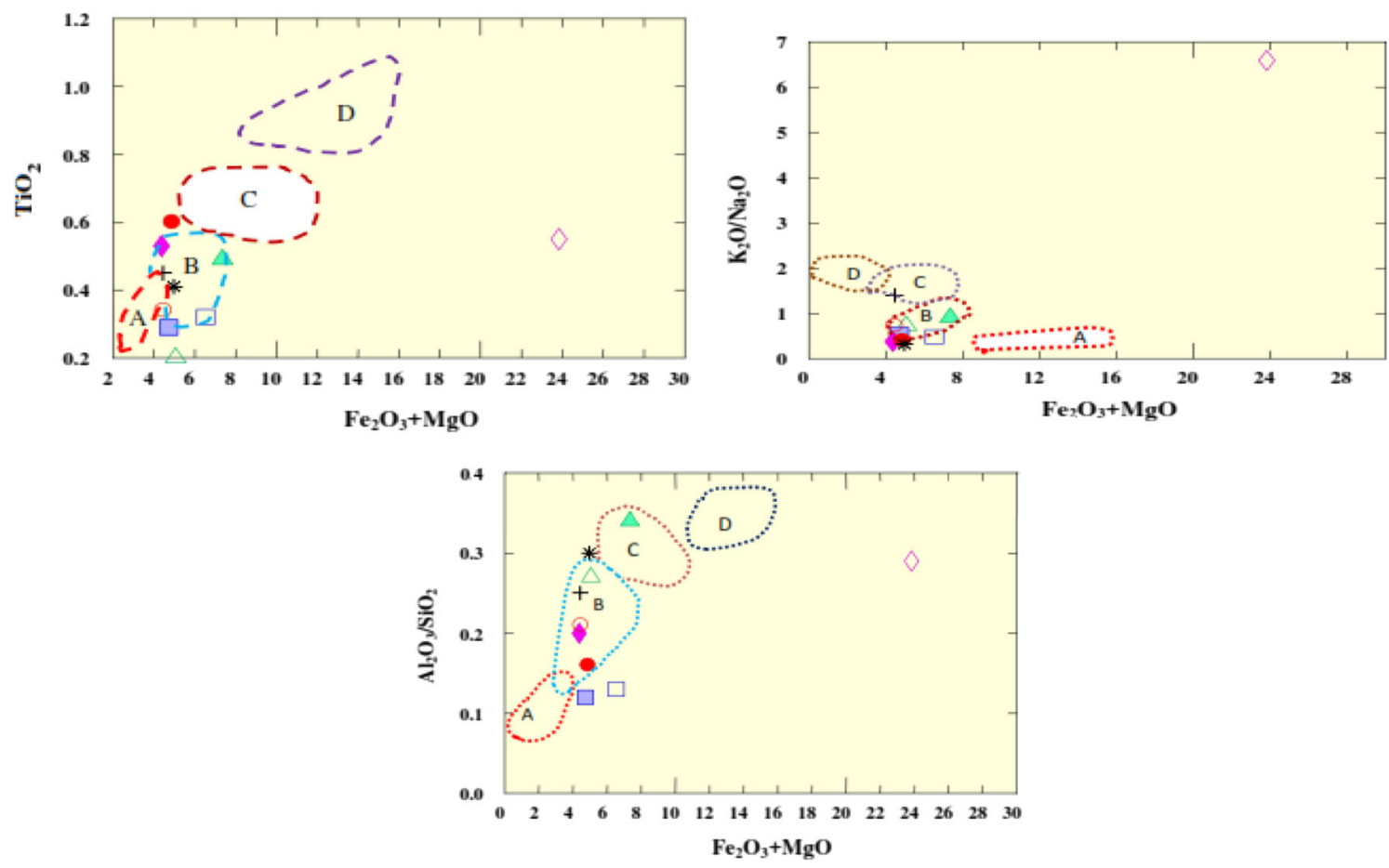

Figure 13. Provenance scatter diagram of Garudamangalam sandstone. Fields A is oceanic island arc, B is continental island arc, $\mathrm{C}$ is active continental margin and $\mathrm{D}$ is passive margin.

\section{Conclusion}

The Garudamangalam Formation sandstones show considerable variations in major, trace and rare earth elements. Major element geochemistry of clastic rocks $\left(\mathrm{Al}_{2} \mathrm{O}_{3}\right.$ vs. $\left.\mathrm{Na}_{2} \mathrm{O}\right)$ plot and trace elemental ratio $(\mathrm{Th} / \mathrm{U})$ reveal the moderate to intense weathering of the source rocks. The $\mathrm{Cr} / \mathrm{Zr}$ ratio of clastic rocks reveal with an average of 1.74 suggesting of felsic provenance. In clastic rocks, high ratios of $\sum L R E E / \sum H R E E, \mathrm{La} / \mathrm{Sc}, \mathrm{Th} / \mathrm{Sc}$, $\mathrm{Th} / \mathrm{Co}, \mathrm{La} / \mathrm{Co}$ and low ratios of $\mathrm{Cr} / \mathrm{Zr}$ and positive $\mathrm{Eu}$ anomaly $\left(\mathrm{Eu} / \mathrm{Eu}^{*}\right)$ ranges from 1.87 to 5.30 reveals felsic nature of the source rocks. The discrimination diagrams for sedimentary provenance after Roser and Korsch (1986), all samples of the studied sandstone plot in the felsic igneous provenance field.

\section{Acknowledgements}

The author wishes to express his gratitude to Dr D Venkateswaran, Vice President, R\&D Center, India Cements, Dalavoi, for providing laboratory facilities, and express his sincere thanks to $\mathrm{M} / \mathrm{s}$ Shiva Analytical Pvt Ltd, Bangalore, India, for ICP-Ms analysis.

\section{References}

Bakkiaraj D, Nagendra R, Nagarajan R and ArmstrongAltrin J S 2010 Geochemistry of siliclastic rocks of Sillakudi Formation, Cauvery basin, southern India: Implications for provenance; J. Geol. Soc. India 76 453-467.

Banerji R K 1972 Stratigraphy and micropalaeontology of the Cauvery Basin. Part I: Exposed area; J. Paleontol. Soc. India 17 1-24. 
Banerji R K et al. 1996 Uttatur group redefined; In: Cretaceous stratigraphy and palaeo-environments; Mem. Geol. Soc. India 37 213-230.

Bhatia M R 1983 Plate tectonics and geochemical composition of sandstones; J. Geol. 91 611-627.

Bhatia M R and Crook K A W 1986 Trace element characteristics of graywackes and tectonic setting discrimination of sedimentary basins; Contrib. Mineral. Petrol. 92 181-193.

Blanford H F 1862 On the Cretaceous and other rocks of South Arcot and Trichinopoly districts; Mem. Geol. Surv. India 4 1-217.

Condie K C 1993 Chemical composition and evolution of the upper continental crust: Contrasting results from surface samples and shales; Chem. Geol. 104 1-37.

Condie K C and Wronkiewicz D A 1990 A new look at the Archaean-proterozoic boundary sediments and the tectonic setting constraints; In: The precambrain continental crust and its economic resources (ed.) Naqvi S M, Elsevier, pp. 61-89.

Condie K C et al. 1992 The origin of Khondalites: Geochemical evidence from the Archaean to early proterozoic granulite belt in the North China Craton; Precamb. Res. 59 207-223.

Cox R and Lowe D R 1995 Compositional evaluation of coarse clastic sediments in the south western United States from 1.8 to 0.2 G.A. and implications for relationships between the development of crustal blocks and their sedimentary cover; J. Sedim. Res. 65A 477-494.

Cullers R L 1994 The controls on the major and trace element variation of shales, siltstones and sandstones of Pennsylvanian-Permian age from uplifted continental blocks in Colorado to platform sediment in Kansas, USA; Geochim. Cosmochim. Acta 58(22) 4955-4972.

Cullers R L 2002 Geochemistry of shales, siltstones and sandstones of Pennsylvanian-Permian age, Colorado, USA: Implications for provenance and metamorphic studies; Lithos 51 305-327.

Cullers R L, Basu A and Suttner L J 1988 Geochemical signature of provenance in sand-size material in soil and stream sediments near the Tabacco Root Batholith, Montana, USA; Chem. Geol. 70 335-348.

Feng R and Kerrich R 1990 Geochemistry of fine-grained clastic sediments in the Archaean Abitibi greenstones belt, Canada: Implications for provenance and tectonic setting; Geochim. Cosmochim. Acta 54 1061-1081.

Heier K S and Billings G K 1978 Rubidium. In: Handbook of geochemistry (ed.) Wedepohl K W, Springer-Verlag, Berlin, pp. 37.k.1-k.3.

Herron M M 1988 Geochemical classification of terrigenous sands and shales from core or log data; J. Sedim. Petrol. 58(5) 820-829.

Holland D H D 1978 The chemistry of the atmosphere and oceans; John Wiley, New York, 351p.

Kafayatullah 2009 Lithofacies, petrography and geochemistry of the Neogene Molasse sequence of Himalayan foreland basin, southwestern Kohat; Ph.D Thesis, National Centre of Excellence in Geology, University of Peshawar, Pakistan.

Landergren S 1978 Vanadium; In: Handbook of Geochemistry (ed.) Wedepohl K W, Springer-Verlag, Berlin, pp. 23.D.123.D. 10

Lee J I et al. 2005 Geochemical characteristics and the provenance of sediments in the Branfield Strait, west Antartica; Marine Geol. 219 81-98.

Lindsey D A et al. 2003 Chemical composition and provenance of the Mesoproterozoic Big Creek, Apple Creek and Gunsight formations, Lemhi group, Central Idaho (Chapter B of Russell G Tysdal, David, Lindsey A and Joseph E Taggart Jr., Correlation, sedimentology, structural setting, chemical composition and provenance of selected formations in Mesoproterozoic Lemhi group, Central Idaho). USGS Prof. Paper 1668-B.

Maynard J B, Valloni R and Yu H S 1982 Composition of modern deep-sea sands from arc related basins; In: Trechforearc geology sedimentation and tectonics on modern and ancient active plate margins (ed.) Leggett J K, Geol. Soc. London. Spec. Publ. 10 551-561.

Mazat E and Shiraki K 1978 Chromium. In: Handbook of geochemistry (ed.) Wedepohl K W, Springer-Verlag, Berlin, pp. 24.A.1-24.O.1.

McLennan S M 1989 Rare earth elements in sedimentary rocks: Influence of provenance and sedimentary processes; Rev. Min. 21 169-200.

McLennan S M and Taylor S R 1991 Sedimentary rocks and crustal evolution, tectonic setting and secular trends; J. Geol. 99 1-21.

McLennan S M, Nance W B and Taylor S R 1980 Rare earth element-thorium correlation in sedimentary rocks and the composition of the continental crust; Geochim. Cosmochim. Acta 44 1833-1839.

McLennan S M et al. 1983 Geochemistry of Archaean shales from the pilbara super group, western Australia; Geochim. Cosmochim. Acta 47 1211-1222.

Mongelli G, Cullers R L and Muelheisen S 1996 Geochemistry of late Cretaceous-Oligicene shales from the Varicolori Formation, southern Apennines, Italy: Implications for mineralogical, grain size control and provenance; Eur. J. Miner. $8733-754$.

Nagarajan R, Madhavaraju J, Nagenra R, Armstrong-Altrin J S and Moutte J 2007a Geochemistry of Neoproterozoic shales of the Rababnpalli Formation, Bhima basin, Northern Karnataka, southern India: Implications for provenance and palaeoredox conditions; Revista Mexicana de Ciencias Geologicas 24 150-160.

Nagarajan R, Madhavaraju J, Armstrong-Altrin J S and Nagendra R 2007b Geochemistry of Neoproterozoic limestones of the Shahabad Formation, Bhima basin, Karnataka, southern India; Geosci. J. 15 9-25.

Nance W B and Taylor S R 1976 Rare earth patterns and crustal evolution I. Australian post-Archaean sedimentary rocks; Geochim. Cosmochim. Acta 40 1539-1551.

Nesbitt H N 1979 Mobility and fractionation of rare earth elements during weathering of a granodiorite; Nature $\mathbf{2 7 9}$ 206-210.

Nesbitt H W and Young G M 1996 Petrogenesis of sediments in the absence of chemical weathering: Effects of abrasion and sorting on bulk composition and mineralogy; J. Sedim. 43 341-358.

Nesbitt H W et al. 1996 Effects of chemical weathering and sorting on the petrogenesis of siliclastic sediments, with implication for provenance studies; J. Geol. 104 525-542.

ONGC 1977 Rock stratigraphy of Cauvery Basin; Mass Media Publication Pvt. Ltd, pp. 1-11.

Oseen C W 1913 Uber den Gultigkeitsbereich der Stokeschen Widerstandformal; Arkiv for Matematic; Astronomi Fysick 9 13-40.

Pettijohn F J et al. 1987 Sand and Sandstones. 2nd edn; Springer, New York, 553p.

Puchelt H 1978 Barium. In: Handbook of geochemistry (ed.) Wedepohl K W, Springer-Verlag, Berlin, pp. 56.k.156.k.8.

Ramanathan S 1968 Stratigraphy of Cauvery Basin with reference to its oil prospects; Mem. Geol. Soc. India 2 153-167.

Ramarao L 1956 Recent contributions to our knowledge of Cretaceous rocks of South India; Proc. Indian Acad. Sci. 44 185-245.

Ramasamy S and Banerji R K 1991 Geology, petrography and systematic stratigraphy of pre-Ariyalur sequence in 
Trichirapalli District, Tamil Nadu, India; J. Geol. Soc. India 37 577-594.

Roddaz M, Viers J, Brusset S, Baby P, Boucayrand C and Herail G 2006 Controls on weathering and provenance in the Amazonian foreland basin: Insights from major and trace element geochemistry of Neogene Amazonian sediments; Chem. Geol. 23 31-65.

Roser B P and Korsch R J 1986 Determination of tectonic setting of sandstone-mudstone suites using $\mathrm{SiO}_{2}$ content and $\mathrm{K}_{2} \mathrm{O} / \mathrm{Na}_{2} \mathrm{O}$ ratio; J. Geol. 94 635-650.

Roser B P and Korsch R J 1988 Provenance signatures of sandstone-mudstone suites determination using discrimination function analysis of major element data; Chem. Geol. 67 119-139.

Sastry M V A et al. 1972 Ostracod fauna of the Ariyalur Group (Upper Cretaceous). Trichirapalli District, Tamil Nadu. Part I: Lithostratigraphy of the Ariyalur Group. Part II: Systematic palaeontology; Pal. Indica. Mem. Geol. Surv. India New Series 40 1-48.

Sawyer E W 1986 The influence of source rock type, chemical weathering and sorting on the geochemistry of clastic sediments from the Quetico metasedimentary belt, Superior Province, Canada; Chem. Geol. 55 77-95.

Schwab F L 1978 Secular trend in the composition of sedimentary rock assemblages - Archaean through phanerozoic time; Geol. 6 532-536.

Shilin Liu, Ge Lin, Yunha Liu, Ye Zhou, Faxiong Gong and Yiyan 2007 Geochemistry of Middle Ologocene-Pliocene sandstones from the Nanpu Sag, Bogai bay basin (eastern China): Implications for provenance, weathering, and tectonic setting; Geochem. J. 41 359-378.
Spalletti L A, Queralt I, Matheos S D, Colombo F and Maggi J 2008 Sedimentary petrology and geochemistry of siliclastic rocks from the upper Jurassic Tordillo Formation (Neuquen basin, western Argentina): Implications for provenance and tectonic setting; J. South Am. Earth. Sci., doi: 10.1016/j.james.

Sundaram R and Rao P S 1979 Lithostratigraphic classification of Uttatur and Trichinopoly Group of rocks in Trichirappalli District, Tamil Nadu; Geol. Surv. India, Misc. Publ. 45 111-119.

Sundaram R and Rao P S 1986 Lithostratigraphy of Cretaceous and palaeocene rocks of Trichirappalli District, Tamil Nadu, South India; Rec. Geol. Surv. India 115 9-23.

Sundaram R et al. 2001 A lithostratigraphic revision and palaeoenvironmental assessment of the Cretaceous system exposed in the onshore Cauvery Basin, southern India; Cretaceous Res. 22 743-762.

Taylor S R and McLennan S M 1985 The continental crust: Its composition and evalution; Blackwell, Oxford, 312p.

Van de Kamp P C and Leake B E 1994 Petrology, geochemistry, provenance and alteration of PennsylvanianPermian arkose, Colorado and Utah; Geol. Soc. Am. Bull. 105 1581-1582.

Veizer J 1973 Sedimentation in geological history recycling vs. evolution or recycling with evolution; Contrib. Mineral. Petrol. 38 261-278.

Wronkiewicz D J and Condie K C 1989 Geochemistry of Archaean shales from the Witwatersrand Super group, South Africa: Source area weathering and provenance; Geochim. Cosmochim. Acta 51 2401-2416. 